\title{
Deep sequencing reveals increased DNA methylation in chronic rat epilepsy
}

\author{
Katja Kobow $\cdot$ Antony Kaspi $\cdot$ K. N. Harikrishnan $\cdot$ Katharina Kiese • \\ Mark Ziemann · Ishant Khurana $\cdot$ Ina Fritzsche $\cdot$ Jan Hauke $\cdot$ Eric Hahnen • \\ Roland Coras $\cdot$ Angelika Mühlebner $\cdot$ Assam El-Osta $\cdot$ Ingmar Blümcke
}

Received: 13 June 2013 / Accepted: 15 August 2013 / Published online: 5 September 2013

(c) The Author(s) 2013. This article is published with open access at Springerlink.com

\begin{abstract}
Epilepsy is a frequent neurological disorder, although onset and progression of seizures remain difficult to predict in affected patients, irrespective of their epileptogenic condition. Previous studies in animal models as well as human epileptic brain tissue revealed a remarkably diverse pattern of gene expression implicating epigenetic changes to contribute to disease progression. Here we mapped for the first time global DNA methylation patterns in chronic epileptic rats and controls. Using methyl-CpG capture associated with massive parallel sequencing (Methyl-Seq) we report the genomic methylation signature of the chronic epileptic state. We observed a predominant increase, rather than
\end{abstract}

K. Kobow and A. Kaspi contributed equally.

Electronic supplementary material The online version of this article (doi:10.1007/s00401-013-1168-8) contains supplementary material, which is available to authorized users.

K. Kobow $(\bowtie) \cdot$ K. Kiese $\cdot$ I. Fritzsche $\cdot$ R. Coras $\cdot$ I. Blümcke Department of Neuropathology, University Hospital Erlangen, Schwabachanlage 6, 91054 Erlangen, Germany

e-mail: katja.kobow@uk-erlangen.de

A. Kaspi · K. N. Harikrishnan · M. Ziemann - I. Khurana ·

A. El-Osta

Epigenetics in Human Health and Disease, Baker IDI

Heart and Diabetes Institute, The Alfred Medical Research

and Education Precinct, Melbourne, VIC, Australia

e-mail: assam.el-osta@bakeridi.edu.au

J. Hauke $\cdot$ E. Hahnen

Center of Familial Breast and Ovarian Cancer, University

Hospital of Cologne, Cologne, Germany

J. Hauke $\cdot$ E. Hahnen

Center for Molecular Medicine Cologne (CMMC), University

of Cologne, Cologne, Germany loss of DNA methylation in chronic rat epilepsy. Aberrant methylation patterns were inversely correlated with gene expression changes using mRNA sequencing from same animals and tissue specimens. Administration of a ketogenic, high-fat, low-carbohydrate diet attenuated seizure progression and ameliorated DNA methylation mediated changes in gene expression. This is the first report of unsupervised clustering of an epigenetic mark being used in epilepsy research to separate epileptic from non-epileptic animals as well as from animals receiving anti-convulsive dietary treatment. We further discuss the potential impact of epigenetic changes as a pathogenic mechanism of epileptogenesis.

Keywords Epilepsy · Hippocampus $\cdot$ Epigenetic $\cdot$ DNA methylation $\cdot$ Massive parallel sequencing $\cdot$ Ketogenic diet

\author{
A. Mühlebner \\ Department of Pediatrics and Adolescent Medicine, Medical \\ University Vienna, Vienna, Austria
}

\section{A. El-Osta}

Epigenomics Profiling Facility, Baker IDI Heart and Diabetes Institute, The Alfred Medical Research and Education Precinct, Melbourne, VIC, Australia
A. El-Osta
Department of Pathology, The University of Melbourne, Parkville, VIC, Australia
A. El-Osta
Faculty of Medicine, Monash University, Melbourne, VIC, Australia 


\section{Introduction}

Approximately $0.5-1 \%$ of people suffers from epilepsy. One frequent epileptic syndrome is associated with drugresistant temporal lobe seizures and hippocampal neurodegeneration, i.e., temporal lobe epilepsy with hippocampal sclerosis (TLE-HS) [9]. Onset with an initial precipitating injury including trauma, inflammation, or prolonged acute symptomatic seizures is most characteristic, followed by a clinically silent latency period before progression of spontaneous recurrent seizures $[7,58]$. This pathogenic time course can be recapitulated in experimental animal models of TLE, although specific disease mechanisms remain poorly understood. Array-based profiling studies have detected aberrant gene expression patterns. Several genes implicated in epilepsy have been identified and are thought to participate in inflammation and stress, synaptic transmission and signal transduction, ion transport, cell metabolism as well as synaptic plasticity $[4,16,22,26,45]$. We recently hypothesized that a common regulatory trait for these abundant and long-lasting changes in gene expression relates to epigenetic changes such as genomic DNA methylation $[34,35]$ as well as specific chromatin changes, including histone tail modification. Recent experimental studies provide some evidence for aberrant epigenetic signatures induced by seizures. For example, alterations in histone tail modifications have been reported for histones $\mathrm{H} 3$ and $\mathrm{H} 4[28,30,69,73]$ as well as phosphorylation of histone variant H2A.X [14]. Furthermore, the neuron restrictive silencing factor (Nrsf), which regulates neuronal gene expression and recruits DNA methyltransferases (Dnmts) as well as histone deacetylases (Hdacs), is involved in seizure development and progression [21, 44, 51]. Altered microRNA expression [31] as well as DNA methylation patterns are also observed in rodent epilepsy models [53]. Our group was the first to show that aberrant DNA methylation of the Reelin promoter associated with granule cell dispersion in human TLE [36]. Furthermore, increased DNMT expression was observed in temporal neocortex samples obtained from TLE patients [79]. The experimental results of these studies implicate aberrant DNA methylation in the late, chronic and drugresistant stage of the disease.

Herein we used a massive parallel sequencing approach to examine persistent changes in genomic $\mathrm{CpG}$ methylation correlated with gene expression in a chronic rat TLE model. Since dietary intake and nutrition are implicated in modifying epigenetic patterns [18], we examined the ketogenic diet (KD) in our model of chronic rat epilepsy. The high-fat, low-carbohydrate ketogenic diet is well recognized as anti-epileptic therapy with moderate success in man and experimental animal models [33, 38, 50, 54]. In this study, we demonstrate that early administration of an anti-convulsive ketogenic diet is associated with gene regulating DNA methylation changes in rat TLE.

\section{Materials and methods}

Animal model: surgery, induction of status epilepticus and video-EEG recording

The experimental study was approved by the local animal care and use committee in accordance with the European Communities Council Directive (54-2532.1-23/09, Directive 2010/63/EU). Male Wistar rats weighting 300-350 g (Charles-River, Germany; $n=14$ ) were kept in individual cages under controlled environmental conditions $(12 \mathrm{~h}$ dark/light cycles, $20-23{ }^{\circ} \mathrm{C}$ and $50 \%$ relative humidity) with drinking and feeding ad libitum. Animals were either fed a standard or ketogenic diet (KD, 4:1 ratio of fat over protein and carbohydrates, specifically designed for rodents and distributed by Altromin, Lage, Germany; data sheet access via http://www.altromin.de/de/upload/media/ specs/sonder/30009.pdf) and weekly controlled for body weight (Supplement Fig. 1a).

Representative animals were assigned to continuous video-electroencephalography monitoring (vEEG; $n=5$; DSI, St. Paul, MN, USA). Electrodes were implanted before seizure induction. Rats were deeply anesthetized with an intraperitoneal injection of a ketamine $(57 \mathrm{mg} /$ $\mathrm{kg})$ and xylazine $(9 \mathrm{mg} / \mathrm{kg})$ mixture and placed in a stereotaxic apparatus (Bilaney Consultants, Düsseldorf, Germany). The skull was exposed and two holes were drilled ( $2 \mathrm{~mm}$ lateral to the sagittal suture and $5 \mathrm{~mm}$ anterior to the lambda suture, $1 \mathrm{~mm}$ diameter) to insert stainless steel screws (1 mm diameter, DIN84, Hummer und Riess, Nuremberg, Germany) passing the bone and touching but not penetrating the dura. Screws were connected with polyimide coated stainless steel lead wire, serving as EEG electrodes. Afterwards, both screws were glued together with lead wires and surrounding bone using dental acrylic. The transmitter (F40-EET, DSI, St. Paul, MN, USA) was placed into a subcutaneous pocket along the animal's dorsal flank. All animals had time to recover for 1 week before further procedures. There were no differences in baseline EEG between animals before further treatment.

To induce status epilepticus (SE), animals were injected with a single high dose of the muscarinic receptor agonist pilocarpine (PILO; 340 mg/kg, i.p.; Sigma-Aldrich, Steinheim, Germany). Peripheral cholinergic effects were minimized by administration of methyl scopolamine $(1 \mathrm{mg} / \mathrm{kg}$, s.c.; $30 \mathrm{~min}$ before injection of pilocarpine; TCI Europe NV, Zwijndrecht, Belgium). Animals that experienced no SE within 45 min after first pilocarpine administration 
were treated for a second time with half the application dosis $(175 \mathrm{mg} / \mathrm{kg}$, i.p.). After $60 \mathrm{~min} \mathrm{SE}$ duration, animals received administration of diazepam $(8 \mathrm{mg} / \mathrm{kg}$, i.m.; Sigma-Aldrich). One hour following diazepam treatment glucose depots $(2 \times 5 \mathrm{ml})$ were subcutaneously injected to help animals to recover. Age matched control rats (CTRL; $n=5)$ received methyl scopolamine and saline $(0.9 \%$ $\mathrm{NaCl}$; Sigma-Aldrich) injections only.

Behavioral seizures were scaled from 1 to 5 according to Racine [61]. SE was defined as minimum three Racine "class 5" behavioral seizures within $10 \mathrm{~min}$ and was identified, where applicable, from EEG recordings by high-amplitude and -frequency discharges. All rats were continuously monitored (video or vEEG, $24 \mathrm{~h} / 7$ days) following pilocarpine injections. The observation period lasted 84 days. Available EEGs (PILO $n=3 / 4$ and PILO $+\mathrm{KD} n=2 / 5$ ) were automatically screened for spontaneous seizure activity using the NeuroScore software (DSI). An EEG seizure was defined as a period of consistent, repetitive changes in amplitude and frequency of electrical activity that persisted for more than $10 \mathrm{~s}$ (Supplement Fig. 1c). Video images were used to confirm a clinical seizure where EEG abnormalities were detected. Behavioural seizures were further evaluated for the following parameters: latency to the appearance of first spontaneous seizure after SE in days; seizure severity according to Racine's scale; seizure duration in seconds; seizure frequency defined as the total number of detected seizures per week and life time seizures.

Neuropathological evaluation of our rat TLE model was performed in video-monitored reference cohorts (CTRL, PILO and PILO $+\mathrm{KD} ; n=3$ each) treated as described above, but terminated 4 weeks following SE or sham injection. A detailed description of method and results is provided in the legend to Supplement Fig. 2.

\section{Tissue preparation}

For tissue preparation ether anesthetized animals were decapitated, the sculls opened and overlaying cortex removed for preparation of dorsal hippocampus. Five-mmthick hippocampal slices were prepared along the septotemporal axis and collected in icecold PBS, thereby, removing blood contamination. Hippocampi were snap frozen in liquid nitrogen and stored at $-80{ }^{\circ} \mathrm{C}$ until further use. Each probe was individually processed and not pooled with other samples. For downstream applications hippocampus was homogenized in ice cold $1 \times$ PBS and divided into equal volumes for DNA and RNA extraction.

\section{DNA methylation profiling}

Ten mg rat hippocampal tissue was used for genomic DNA extraction using the DNeasy Blood and Tissue Kit (Qiagen,
Hilden, Germany) according to the manufacturer's instructions. Massive parallel sequencing of enriched methylated DNA was performed as described previously [57]. Briefly, $500 \mathrm{ng}$ of rat hippocampal DNA from each animal $(n=14)$ was fragmented to a median size of 200-300 bp and subjected to methylated DNA capture according to the MethylMiner protocol (Invitrogen, Darmstadt, Germany), exclusively enabling capture of methylated double stranded DNA. Fragmented and enriched DNA was eluted at high salt concentrations $(2 \mathrm{M} \mathrm{NaCl})$. Ten ng of enriched DNA was used in library preparation using the NEBNext DNA Library Prep Reagent Set for Illumina (New England Biolabs, Frankfurt/Main, Germany). Quality of sequencing libraries was assayed using the Shimadzu MultiNA capillary electrophoresis system (Shimadzu, Kyoto, Japan). Libraries were sequenced at a concentration of $10 \mathrm{pM}$ on the Illumina Genome Analyzer IIx (Illumina, San Diego, CA, USA) with a 36 bp single read length. Image analysis and base-calling were performed with OLBv1.8 software. Sequenced tags were aligned to the rat genome RN4 using BWA (version 0.5.9) with default alignment parameters [43]. Profiles of DNA methylation were compared between all pairwise combinations of samples using the MACS peak calling software (version 1.4.0 rc2) with a fixed shift size of $75 \mathrm{bp}$ and a significance cut-off of 10E-05 [78]. Genomic regions showing different methylation patterns between pairs of samples were merged using Bedtools [59]. Duplicate reads which aligned to the same location in a given sample were removed from further analysis. The numbers of read tags aligning to each region were summarized using a custom python script producing a matrix of counts (tags per region per sample). The regions were non-differentially filtered for regions, where the sum of tag counts was below the 50th centile. These count data were tested for differential tag abundance using Bayesian shrinkage of a negative binomial model implemented in edgeR [64], and normalized using trimmed mean normalization [65]. An adjusted $p$ value was calculated using the Benjamini-Hochberg false discovery rate (FDR) [6]. Filtered gene lists meeting our significance criteria were submitted to pathway analysis using resources supplied by the database for annotation, visualization and integrated discovery (DAVID) [27].

\section{Gene expression profiling}

Ten mg rat hippocampal tissue was used for total RNA extraction using the Trizol method, followed by DNAse digestion. RNA quality was verified on the Shimadzu MultiNA capillary electrophoresis system (Shimadzu). Following Dynabead Oligo(dT) enrichment (Invitrogen), mRNA was prepared into sequence ready libraries with the NEBNext mRNA Library Prep Reagent Set for Illumina (New England Biolabs). These samples were sequenced 
as above. Sequenced tags were aligned to the rat genome RN4 using BWA (version 0.5.9) using default alignment parameters [43]. The numbers of read tags aligning to each gene were extracted using a custom python script producing a matrix of counts with regions based on the Ensembl transcript annotation (version 66). Genes were non-differentially filtered for tag counts sums below the 30th centile. This count data was tested for differential tag abundance using Bayesian shrinkage of a negative binomial model implemented for in edgeR [64], and normalized using trimmed mean normalization [65]. An adjusted $p$ value was calculated using the Benjamini-Hochberg false discovery rate (FDR) [6].

Gene set enrichment analysis of expression

Rank scores for differential mRNA expression were calculated as $-\log 10$ ( $p$ value) multiplied by the sign of the edgeR fold change so that upregulated genes had positive scores. These rank scores were used to test for correlations between mRNA expression and DNA methylation or ChIPSeq derived gene sets using the GSEA preranked method based on 1,000 gene set permutations [72]. Sets of differentially methylated genes were derived by taking the differentially methylated regions for each pairwise comparison between PILO, and PILO + KD with CTRL filtered for a $p$ value $<0.01$ as determined by edge $R$ analysis, and separated into increased and decreased methylation. If any of these regions were co-located with either a gene body, TSS, promoter ( $-3 \mathrm{~kb}$ from TSS), exon or intron they were assigned to that gene set, e.g., genes with an exon overlapping a region of increased methylation. The clustered transcription factor data set was downloaded (ftp://hgdownload.cse.ucsc.edu/ apache/htdocs/goldenpath/hg 19/encodeDCC/apache/ htdocs/goldenpath/hg19/encodeDCC/wgEncodeRegTfbsClus tered/) from the ENCODE profiling project [17]. A gene set for each transcription factor and cell line was generated by intersecting ChIP-Seq data with promoter annotation $(-3 \mathrm{~kb}$ from TSS) using Ensembl human genes (version 66), and assigning the intersecting gene promoters to that gene set. This analysis generated 425 gene sets, of which 403 (depending on gene set size) were used in GSEA. Rat genes were mapped to Human genes using Homologene [1].

Quantification of gene expression

Total RNA was isolated using TRIzol (Invitrogen). Genomic DNA contamination was removed by DNAse treatment (Qiagen). First-strand cDNA synthesis was performed using the SuperScript II first strand synthesis Kit (Invitrogen) according to the manufacturer's instructions. Gene expression was analyzed on an ABI Prism 7500 Fast Real-Time PCR Detection System (Applied Biosystems,
Foster City, CA, USA). Forward and reverse primers were used at $100 \mathrm{nM}$ together with Power SYBR Green Master Mix (Applied Biosystems). Reactions were incubated at $95{ }^{\circ} \mathrm{C}$ for $10 \mathrm{~min}$, followed by 40 cycles of $95^{\circ} \mathrm{C}$ for $10 \mathrm{~s}$ and $60{ }^{\circ} \mathrm{C}$ for $30 \mathrm{~s}$. For relative quantification (comparative $\Delta \Delta \mathrm{Ct}$ method), gene expression was assessed at least in triplicates and normalized to internal reference Actb and Gapdh. cDNA specific primers were designed as follows: Camkk2 fw-AGAACTGCACACTGGTCGAG, rev-CCGGCTACCTTCAAATGGGT; $1 l 10 r b$ fw-CTGGAGCCATGGACAACTTACT, rev-GGAGGGGTTGTTTCATCACTG; Actb fw-GAGAAGAGCTATGAGCTGCC, rev-TCCATACCCAGGAAGGAAGG; Gapdh fw-GGCTGGCATTGCTCTCAATG, rev-CATGTAGGCCATGAGGTCCA.

\section{Bisulfite sequencing}

DNA samples were processed for methylation-specific sequencing as described previously [25, 36]. Briefly, $1 \mu \mathrm{g}$ of genomic DNA was bisulfite converted using EpiTect DNA Bisulfite Kit (Qiagen), the region of interest pre-amplified, subcloned using topoisomerase TA vector (Invitrogen) and white colonies were selected and grown in LB broth. Plasmid was purified using Gene Jet Plasmid Miniprep Kit (Fermentas, St. Leon-Rot, Germany) and clones sequenced (commercial sequencing facility of GATC Biotech, Konstanz, Germany). A minimum of six clones per subject with proven insertion of the PCR fragment were analyzed. Sequences were quality controlled and aligned using the CLC sequence viewer v. 6.3 (CLC bio) and Quantitation tool for Methylation Analysis software (RIKEN). Primers used for bisulfite sequencing were the following: Camkk2_BIS fw-TTTAGAGGGGATTTGAGTTTTT, rev-ATCCACCAATAAATCCAAATATTAC; Illorb_BIS fw-GGGTTAGGATTGAGTTTGTAGAT, revTAAATAATAAAACCACCAAATTTATACTC.

\section{Data access}

Methyl-Seq and mRNA-Seq data were deposited in the NCBI Gene Expression Omnibus (GEO; http://www.ncbi.n $1 \mathrm{~m}$.nih.gov/geo/query/acc.cgi?acc=GSE50080).

\section{Results}

Massive parallel sequencing identifies distinct genomic DNA methylation profiles in chronic rat epilepsy compared with controls

DNA methylation is a major epigenetic regulator of gene suppression [52], and has been implicated in experimental and human temporal lobe epilepsies [36, 53, 79]. However, 
our knowledge on genomic methylation mediating gene expression changes in epilepsy is limited (1) to few specific gene loci comprehensively analyzed and (2) to the early stage of the disease (during or immediately following SE). To examine the role of genomic DNA methylation in the chronic epileptic state, we used Methyl-capture and massive parallel sequencing (Methyl-Seq) of hippocampal tissue obtained from rats 12 weeks following pilocarpine induced status epilepticus (PILO, $n=4$ ) and compared these with respective healthy controls (CTRL, $n=5$ ). We also examined gene expression changes using mRNA sequencing (mRNA-Seq) from the same tissue specimens to analyze the biological relevance of methylation changes (Fig. 1a).

Whole-genome DNA methylation profiling was performed as previously described [12, 57]. A minimum of 15 million short single reads (36 bp) was sequenced per sample, and an average $83 \%$ of the short reads mapped unambiguously to the rat genome (RN4). The other $17 \%$ of reads were likely to originate from repetitive DNA. Interindividual sample comparison revealed 310,070 regions covering $203,265,410$ bp with variant methylation ( 7.3\% of the rat genome). Pairwise comparison of global DNA methylation detected strong differences in methylation patterns between all CTRL and PILO samples. Hierarchical cluster analysis was used to assess and visualize underlying differences in DNA methylation profiles between samples and phenotypes. As shown in Fig. 1b, DNA methylation profiles readily discriminated samples into discrete groups according to the treatment.
To further examine changes in DNA methylation and its association with phenotype we mapped methylation profiles to the rat genome using Circos [39]. Increased (hyper-) and decreased (hypo-) methylation in PILO samples were assigned to each chromosome and shown in red and green, respectively (Fig. 2a). We observed phenotype-specific regionalization of hyper- and hypomethylation events, which targeted the entire genome except chromosome X. Our analysis identified 2,573 individual loci that discriminate between chronic epileptic and control animals (cut-off $p<0.01$ ). Thereof, 1,452 loci were hypermethylated and 1,121 loci hypomethylated in chronic epilepsy samples compared to controls. These data imply that DNA methylation patterns of PILO animals are indeed distinguishable from the reference CTRL animals.

Differential DNA methylation in chronic rat epilepsy is mainly confined to gene bodies

Because hypermethylation of CpG-rich promoters is commonly regarded as a strong indicator of gene suppression in physiologic and pathologic conditions [77], we examined the extent of DNA methylation at different genomic regions. We compared the distribution of genomic methylation at $\mathrm{CpG}$ islands (CGI), non-genic and genic regions (gene body including $5^{\prime}$ and $3^{\prime}$ untranslated regions), promoters (3 kb upstream of transcription start), transcriptional start sites (TSS) and exons as well as introns in the dissected hippocampi of chronic epileptic animals relative to controls. Differentially methylated regions were

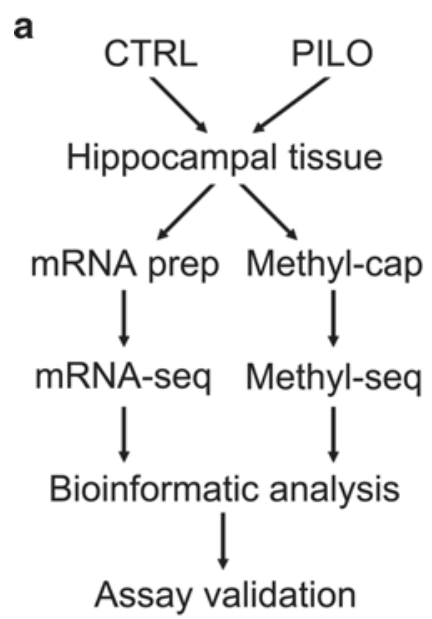

Fig. 1 Deep sequencing (Methyl-Seq) revealed increased genomic DNA methylation in chronic rat epilepsy. a Study design, b heat map displaying hierarchical clustering of samples and genomic regions according to differential methylation profiles (yellow methylation up, red methylation down). A specific DNA methylation signature characterized chronic rat epilepsy. CTRL sham injected, healthy controls; $P I L O$ pilocarpine injected, chronic epileptic animals. Clustering was

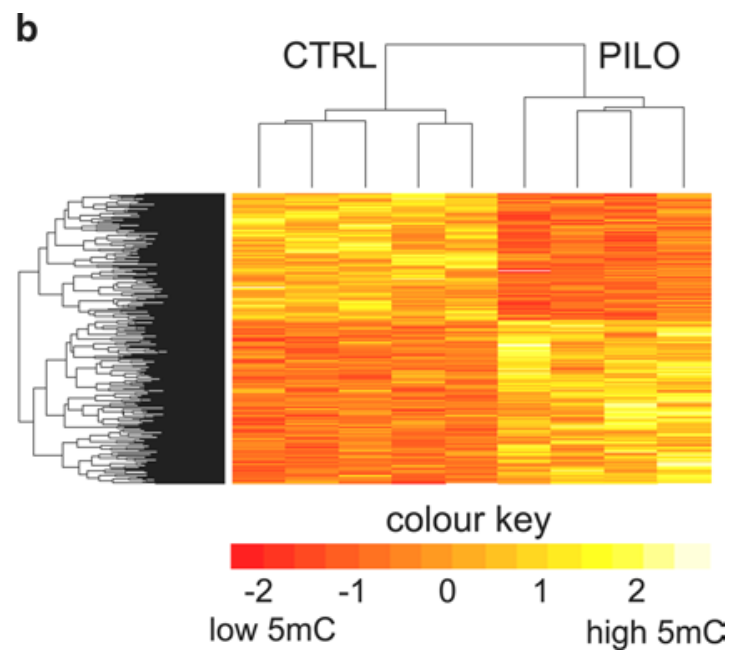

performed by taking the trimmed mean normalized values for differential regions as defined by edgeR analysis with a $p$ value $<0.01$. These values were normalized to the standard normal distribution before performing Euclidean distance based hierarchical clustering on both regions and samples using the heatmap. 2 function in the $\mathrm{R}$ package gplots 

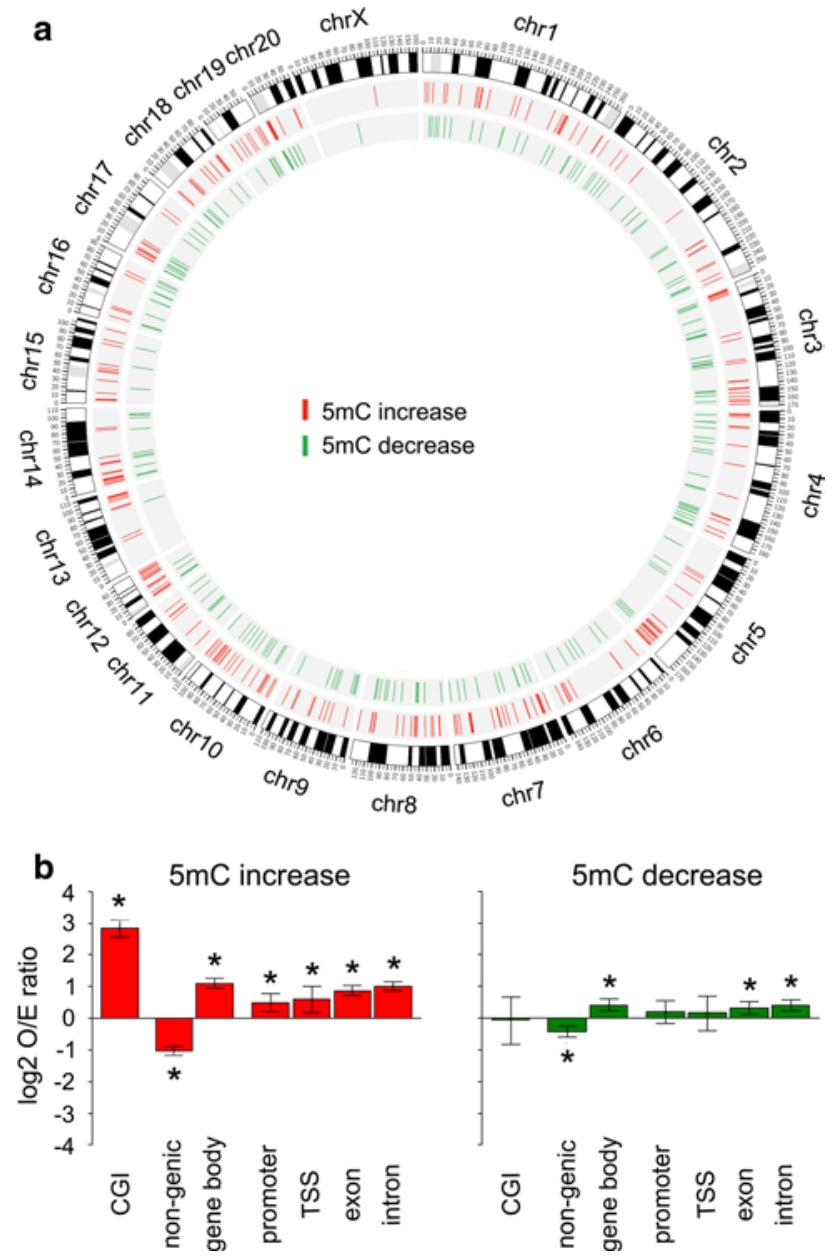

Fig. 2 Genomic distribution of DNA methylation changes (cut-off $p<0.01)$ in chronic rat epilepsy. a Rat genome ideogram summarizing hypermethylation (red) and hypomethylation events (green) in PILO versus CTRL. DNA methylation targeted the entire genome with almost complete sparing of the $\mathrm{X}$-chromosome ( $\mathrm{ChrX})$. b Frequency of observed methylation changes compared to non-differentially methylated regions $[-\log 10$ ( $p$ value) $<0.25]$, with upper and lower $95 \%$ confidence intervals for different genomic features. Hypermethylation relative to controls is shown in the left panel (red bars), whereas, hypomethylation relative to controls is shown in the right panel (green bars). DNA methylation events were mainly confined to CGIs, but did not frequently target promoters. $C G I \mathrm{CpG}$ island, TSS transcriptional start site, $O / E$ observed/expected ratio, $5 m C 5$-methyl-cytosin. Asterisks indicate significance $(p<0.05$ using Fisher's Exact test)

normalized and expressed as $\log 2$ odds ratios of observed differences compared to non-differentially methylated genomic features. We report the mean frequency of methylation changes with upper and lower $95 \%$ confidence intervals for the genomic features (Fig. 2b). We identified a significant increase in DNA methylation content in chronic epilepsy specimen, when comparing hyper- and hypomethylation events at specific genomic features. Table 1 shows predominant increase in DNA methylation at CGIs and gene bodies, exons as well as introns (Fisher's Exact Test, $p<0.05)$. Generally, DNA methylation changes were frequently found at $\mathrm{CpG}$ islands (CGI) as well as genic and non-genic regions. Regarding non-genic sites, we did not so much observe differential methylation of gene promoters (Fig. 2b). Instead, we detected changes more readily distal from coding regions of genes.

Gene expression profiling in chronic epileptic rats

We have previously postulated DNA methylation changes as potential cause of aberrant gene expression in experimental and human TLE [34, 35]. To test this hypothesis, we compared genomic methylation patterns with gene expression data derived from same hippocampal specimens using mRNA-Seq ( $n=3$ per treatment group). Gene expression profiling identified 1,502 genes that were differentially expressed in chronic epileptic rats compared to healthy controls (cut-off $p<0.01$; Fig. 3). Gene annotation in DAVID [27] revealed biological functions implicated in pathomechanisms underlying chronic epilepsy, which was consistent with previous reports from animal and human studies using epileptic brain tissue. KEGG pathway analysis of downregulated genes in chronic epileptic hippocampi $(n=517)$ showed enrichment for MAPK and calcium signaling, axon guidance, long-term depression and potentiation, whereas overexpressed genes $(n=985)$ were associated with pathways participating in chronic inflammation, immune response, and neurodegeneration (Table 2).

Furthermore, we observed a large number of seizurerelated genes [40] to be differentially expressed in PILO animals, including voltage-gated calcium, potassium or sodium channels (Cacng2, Itpr1, Kcna1, Kcna2, Kcnq2, Scn4b, Scn8a), calcium pumps (Atp2a2), neurotransmitter receptors (Gabrd), G-protein-coupled receptors (Gpr56) as well as components of the cytoskeleton (Gfap), proteins implicated in cell adhesion (Pcdh19), transcription factors (Tgif1) and metabolic enzymes (Ndufa2, Npc2) shown in Table 3. We also identified genes, which have not been previously associated with brain function, seizure generation or epilepsy-related processes.

Recent experimental results in human TLE detected altered expression of DNMT isoforms [79]. These enzymes are involved in the establishment or maintenance of genomic DNA methylation patterns [19, 55, 79]. Analysis of our mRNA-Seq data revealed no significant change in gene expression for the DNA methyltransferases Dnmt1, Dnmt3a and Dnmt3b in the PILO cohort. But chromatin structure and function may not exclusively be regulated through DNA methylation. We report differential gene expression of other key epigenetic enzymes and downstream effector proteins implicated in histone acetylation and methylation, as well as micro RNA processing and 
Table 1 Genomic features targeted by DNA methylation

\begin{tabular}{lcccccrrr}
\hline Feature & Up_OL & Up_NOL & Down_OL & Down_NOL & log2 odds ratio & Lower CI & Upper CI & $p$ value \\
\hline CGI & 148 & 1,304 & 17 & 1,104 & 2.881 & 2.142 & 3.708 & $9.7 \mathrm{E}-22$ \\
Gene body & 831 & 621 & 510 & 611 & 0.681 & 0.450 & 0.912 \\
Non-genic & 692 & 760 & 651 & 470 & -0.605 & -0.836 & -0.374 & $1.8 \mathrm{E}-09$ \\
Intron & 783 & 669 & 489 & 632 & 0.597 & 0.366 & 0.828 & $2.3 \mathrm{E}-07$ \\
Exon & 438 & 1,014 & 255 & 866 & 0.553 & 0.289 & 0.818 & $2.5 \mathrm{E}-05$ \\
Promoter & 108 & 1,344 & 69 & 1,052 & 0.293 & -0.173 & 0.766 & $2.1 \mathrm{E}-01$ \\
TSS & 53 & 1,399 & 31 & 1,090 & 0.413 & -0.264 & 1.113 & $2.2 \mathrm{E}-01$ \\
\hline
\end{tabular}

Table shows statistics comparing ratio of the number of increased versus decreased methylated regions (cut-off $p<0.01$ ) across genomic features. $p$ value calculated with Fisher's exact test $(p<0.05$ was considered significant)

$C G I \mathrm{CpG}$ island, TSS transcriptional start site, $O L$ number of loci overlapping feature (overlap $\geq 1 \mathrm{bp}$ ), NOL number of loci not overlapping feature, $C I$ confidence interval

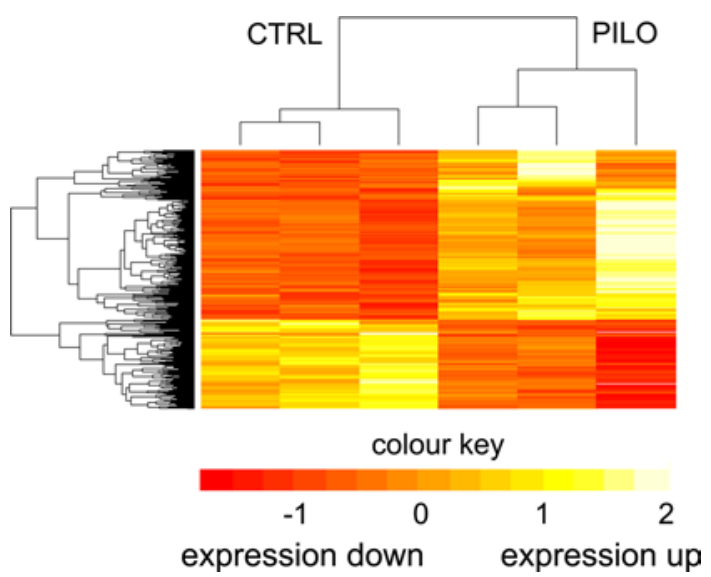

Fig. 3 mRNA-Seq identified highly distinct gene expression signatures in chronic rat epilepsy and controls. Heat map displaying hierarchical clustering of samples and genes according to differential expression profiles normalized to the standard normal distribution (yellow expression up, red expression down). Treatment groups can be clearly differentiated by their expression profiles. CTRL sham injected, healthy controls; PILO chronic epileptic animals. Clustering was performed by taking the trimmed mean normalized values for genes as defined by edgeR analysis with a $p$ value $<0.01$. These values were normalized to the standard normal distribution before performing Euclidean distance based hierarchical clustering on both regions and samples using the heatmap. 2 function in the $\mathrm{R}$ package gplots

ATP-dependent chromatin remodeling (manual inspection and GO term analysis, cut-off $p<0.01$, Table 4). These results suggest that different epigenetic pathways could be involved in the pathogenesis of epilepsy and maintenance of the chronic disease state.

DNA methylation is inversely correlated with gene expression in chronic epileptic rats

Next we determined whether DNA methylation changes targeted gene expression in our model of chronic epilepsy. A Gene Set Enrichment Analysis (GSEA) was performed
[72] using the ranked mRNA results and sets of differentially methylated genes as described above. In PILO animals, differential DNA methylation targeted 1,180 specific gene loci (overlap $\geq 1$ bp with annotated promoter, TSS or gene body). Generally, these DNA methylation changes were not associated with alterations in gene expression $(n=930,79 \%)$. However, for 250 gene loci $(21 \%)$ a strong correlation between differential DNA methylation and gene expression was identified. DNA hypermethylation of gene bodies, introns as well as exons was clearly associated with gene silencing in chronic rat epilepsy, but we did not find hypermethylation of gene promoters correlated with gene suppression (Fig. 4 upper panel, and Supplement Table 1). In contrast, decreased methylation was associated with increased gene expression and a feature of exons, introns, TSS and gene promoters (Fig. 4 lower panel, and Supplement Table 1).

To understand biological pathways targeted by altered gene expression patterns and DNA methylation, we performed Functional Annotation Clustering using DAVID. This analysis identified enrichment of genes implicated in cytoskeleton organization, immune response and inflammation, neuronal development and differentiation, cell adhesion, as well as cell projection. Furthermore, we observed changes in genes involved in calcium signaling, DNA binding and transcription, programmed cell death, and synaptic transmission (enrichment score for all clusters $>1.5$ ). Taken together, GSEA would support a biological relevance of DNA methylation changes in our experimental epilepsy model.

Validation of candidate genes in epilepsy

Next we sought to validate DNA methylation targeted gene expression. Bisulfite sequencing was used to verify differential methylation from Methyl-Seq in chronic rat epilepsy compared to healthy controls. To quantify differences in $\mathrm{CpG}$ methylation between PILO and CTRL, 
Table 2 Functional enrichment of GO terms and KEGG pathways in chronic rat epilepsy gene expression

\begin{tabular}{|c|c|c|c|c|c|}
\hline Term & Count & $p$ value & Term & Count & $p$ value \\
\hline \multicolumn{6}{|l|}{ GO terms } \\
\hline GO: molecular function & & & GO: biological process & & \\
\hline GO: 0003779—actin binding & 27 & $1.8 \mathrm{E}-04$ & GO: 0006955—immune response & 50 & $1.8 \mathrm{E}-07$ \\
\hline $\begin{array}{l}\text { GO: } 0004714 \text {-transmembrane recep- } \\
\text { tor tyrosine kinase activity }\end{array}$ & 10 & $1.1 \mathrm{E}-03$ & $\begin{array}{l}\text { GO: 0043067-regulation of programmed } \\
\text { cell death }\end{array}$ & 63 & $4.3 \mathrm{E}-05$ \\
\hline GO: 0051015—actin filament binding & 8 & $6.9 \mathrm{E}-03$ & GO: 0007610—behavior & 44 & $5.2 \mathrm{E}-05$ \\
\hline $\begin{array}{l}\text { GO: } 0016563 \text { - transcription activator } \\
\text { activity }\end{array}$ & 25 & $1.1 \mathrm{E}-02$ & GO: 0016477—cell migration & 31 & $6.7 \mathrm{E}-05$ \\
\hline $\begin{array}{l}\text { GO: } 0005272 \text { - sodium channel } \\
\text { activity }\end{array}$ & 6 & $1.3 \mathrm{E}-02$ & GO: 0007155—cell adhesion & 46 & $9.6 \mathrm{E}-05$ \\
\hline $\begin{array}{l}\text { GO: } 0022890 \text {-inorganic cation trans- } \\
\text { membrane transporter activity }\end{array}$ & 15 & $1.4 \mathrm{E}-02$ & GO: 0030100 -regulation of endocytosis & 11 & $1.3 \mathrm{E}-03$ \\
\hline GO: 0005216 -ion channel activity & 28 & $1.5 \mathrm{E}-02$ & $\begin{array}{l}\text { GO: 0060627-regulation of vesicle- } \\
\text { mediated transport }\end{array}$ & 15 & $2.8 \mathrm{E}-03$ \\
\hline GO: 0005261 — cation channel activity & 22 & $1.8 \mathrm{E}-02$ & $\begin{array}{l}\text { GO: } 0050804-\text { regulation of synaptic } \\
\text { transmission }\end{array}$ & 19 & $3.6 \mathrm{E}-03$ \\
\hline $\begin{array}{l}\text { GO: } 0005262 \text {-calcium channel } \\
\text { activity }\end{array}$ & 9 & $2.3 \mathrm{E}-02$ & $\begin{array}{l}\text { GO: } 0048167 \text {-regulation of synaptic } \\
\text { plasticity }\end{array}$ & 12 & $4.1 \mathrm{E}-03$ \\
\hline $\begin{array}{l}\text { GO: } 0005244-\text { voltage-gated ion } \\
\text { channel activity }\end{array}$ & 16 & $3.1 \mathrm{E}-02$ & GO: 0048666-neuron development & 31 & $7.6 \mathrm{E}-03$ \\
\hline \multicolumn{6}{|l|}{ KEGG pathways } \\
\hline Downregulated genes & & & Upregulated genes & & \\
\hline rno04020: calcium signaling pathway & 15 & $2.2 \mathrm{E}-05$ & $\begin{array}{l}\text { rno04610: complement and coagulation } \\
\text { cascades }\end{array}$ & 14 & $1.4 \mathrm{E}-06$ \\
\hline rno04010: MAPK signaling pathway & 17 & $1.2 \mathrm{E}-04$ & rno00190: oxidative phosphorylation & 16 & $1.6 \mathrm{E}-04$ \\
\hline rno04360: axon guidance & 9 & $4.9 \mathrm{E}-03$ & rno05012: Parkinson's disease & 15 & $7.8 \mathrm{E}-04$ \\
\hline rno04730: long-term depression & 6 & $1.2 \mathrm{E}-02$ & $\begin{array}{l}\text { rno04612: antigen processing and } \\
\text { presentation }\end{array}$ & 11 & $1.5 \mathrm{E}-03$ \\
\hline rno04720: long-term potentiation & 6 & $1.3 \mathrm{E}-02$ & $\begin{array}{l}\text { rno04650: natural killer cell mediated } \\
\text { cytotoxicity }\end{array}$ & 11 & $3.9 \mathrm{E}-03$ \\
\hline rno04912: GnRH signaling pathway & 7 & $1.4 \mathrm{E}-02$ & rno05016: Huntington's disease & 15 & $1.1 \mathrm{E}-02$ \\
\hline $\begin{array}{l}\text { rno04070: phosphatidylinositol signal- } \\
\text { ing system }\end{array}$ & 6 & $1.5 \mathrm{E}-02$ & $\begin{array}{l}\text { rno04514: cell adhesion molecules } \\
\text { (CAMs) }\end{array}$ & 12 & $2.2 \mathrm{E}-02$ \\
\hline rno04144: endocytosis & 10 & $2.4 \mathrm{E}-02$ & rno05010: Alzheimer's disease & 14 & $3.2 \mathrm{E}-02$ \\
\hline
\end{tabular}

$G O$ gene ontology, KEGG Kyoto encyclopedia of genes and genomes, count number of genes from our data set contributing to GO term and KEGG pathway enrichment, rno Rattus Norvegicus

Mann-Whitney $U$ test was performed. Fisher's Exact Test was further calculated to analyze the independence of $\mathrm{CpG}$ methylation between two treatment groups at a particular CpG site. The schematic shown in Fig. 5 (middle panel) illustrates the gene and its chromosomal localization as well as the location of the amplicon examined using bisulfite sequencing. We confirmed the hypermethylation status of Camkk2 $\left(\mathrm{Ca}^{2+} /\right.$ Calmodulin-dependent protein kinase kinase 2, beta; RN4 genome assembly, chr12:3493640834936667; Mann-Whitney $U$ test $p=1 \mathrm{E}-07$; Fig. 5a, left panel; Supplement Table 2a), a key enzyme in $\mathrm{Ca}^{2+}$ signaling involved in hippocampus-dependent long-term memory, and hypomethylation of the Il10rb locus (interleukin 10 receptor, beta; RN4, chr11:31381431-31381722;
Mann-Whitney $U$ test $p=1 \mathrm{E}-06$; Fig. 5b, left panel; Supplement Table 2b), an endogenous cytokine receptor involved in anti-inflammation and neuroprotection, in chronic rat epilepsy compared to healthy controls.

We further validated gene expression changes identified by mRNA-Seq using qRT-PCR. Camkk2 gene expression was significantly reduced in PILO animals (unpaired two-tailed $t$ test, $p=6.0 \mathrm{E}-04$; Fig. 5a, right panel) and consistent with increased gene methylation. Increased expression of Il10rb (unpaired two-tailed $t$ test, $p=9.3 \mathrm{E}-$ 03; Fig. 5b, right panel) was inversely correlated with a hypomethylation phenotype in chronic rat epilepsy. These results confirm gene expression changes mediated by DNA methylation, as identified in our genome-wide sequencing 
Table 3 Differential gene expression of epilepsy-related genes

\begin{tabular}{|c|c|c|c|c|c|c|}
\hline Gene ID & Gene name & Seizure-related disorder & Ensembl transcript ID & $\log \mathrm{FC}$ & $p$ value & FDR \\
\hline $\operatorname{Scn} 4 b$ & $\begin{array}{l}\text { Sodium channel, voltage- } \\
\text { gated, type IV, beta }\end{array}$ & $\begin{array}{l}\text { Long QT syndrome; } \\
\text { Jervell-Lange Nielsen } \\
\text { syndrome }\end{array}$ & ENSRNOT00000030152 & -2.2 & $5.9 \mathrm{E}-13$ & $5.3 \mathrm{E}-10$ \\
\hline Gfap & Glial fibrillary acidic protein & Alexander disease & ENSRNOT00000034401 & 1.7 & $1.2 \mathrm{E}-09$ & $4.9 \mathrm{E}-07$ \\
\hline $\mathrm{Npc} 2$ & $\begin{array}{l}\text { Niemann-Pick disease, type } \\
\quad \text { C2 }\end{array}$ & Niemann-Pick disease & ENSRNOT00000016076 & 1.2 & $9.6 \mathrm{E}-07$ & $1.8 \mathrm{E}-04$ \\
\hline Itpr1 & $\begin{array}{l}\text { Inositol 1,4,5-triphosphate } \\
\text { receptor, type } 1\end{array}$ & $\begin{array}{l}\text { Itpr } 1^{-l-} \text { with seizure phe- } \\
\text { notype; Spinocerebellar } \\
\text { ataxia }\end{array}$ & ENSRNOT00000009288 & -1.2 & $1.1 \mathrm{E}-06$ & $2.0 \mathrm{E}-04$ \\
\hline Pcdh19 & Protocadherin 19 & $\begin{array}{l}\text { Early infantile epileptic } \\
\text { encephalopathy }\end{array}$ & ENSRNOT00000042335 & -1.2 & $9.2 \mathrm{E}-06$ & $1.2 \mathrm{E}-03$ \\
\hline Gabrd & $\begin{array}{l}\text { Gamma-aminobutyric acid } \\
\text { (GABA) A receptor, delta }\end{array}$ & GEFS+; IGE; JME & ENSRNOT00000022246 & -0.9 & $1.3 \mathrm{E}-04$ & $8.9 \mathrm{E}-03$ \\
\hline Kcna1 & $\begin{array}{l}\text { Potassium voltage-gated } \\
\text { channel, shaker-related } \\
\text { subfamily, member } 1\end{array}$ & $\begin{array}{l}\text { Episodic ataxia; partial } \\
\text { epilepsy }\end{array}$ & ENSRNOT00000026731 & -1.1 & $1.9 \mathrm{E}-04$ & $1.1 \mathrm{E}-02$ \\
\hline Tgif1 & $\begin{array}{l}\text { TGFB-induced factor home- } \\
\text { obox } 1\end{array}$ & Holoprosencephaly & ENSRNOT00000021534 & 1.5 & $2.7 \mathrm{E}-04$ & $1.5 \mathrm{E}-02$ \\
\hline Cacng2 & $\begin{array}{l}\text { Calcium channel, voltage- } \\
\text { dependent, gamma } \\
\text { subunit } 2\end{array}$ & $\begin{array}{l}\text { Cacng } 2^{-/-} \text {with seizure } \\
\text { phenotype; Absence epi- } \\
\text { lepsy; mental retardation }\end{array}$ & ENSRNOT00000008414 & -0.9 & $1.5 \mathrm{E}-03$ & $4.8 \mathrm{E}-02$ \\
\hline Ndufa2 & $\begin{array}{l}\text { NADH dehydrogenase } \\
\text { (ubiquinone) } 1 \text { alpha sub- } \\
\text { complex, } 2\end{array}$ & Leigh syndrome & ENSRNOT00000023811 & 0.9 & $1.7 \mathrm{E}-03$ & $5.0 \mathrm{E}-02$ \\
\hline $\operatorname{Scn} 8 \mathrm{a}$ & $\begin{array}{l}\text { Sodium channel, voltage } \\
\text { gated, type VIII, alpha } \\
\text { subunit }\end{array}$ & $\begin{array}{l}\text { Cerebellar atrophy, ataxia } \\
\text { and mental retardation }\end{array}$ & ENSRNOT00000008160 & -1.0 & $2.1 \mathrm{E}-03$ & $5.8 \mathrm{E}-02$ \\
\hline Gpr56 & $\begin{array}{l}\text { G protein-coupled } \\
\text { receptor } 56\end{array}$ & Polymicrogyria & ENSRNOT00000020921 & -0.8 & $2.4 \mathrm{E}-03$ & $6.1 \mathrm{E}-02$ \\
\hline Kenq2 & $\begin{array}{l}\text { Potassium voltage-gated } \\
\text { channel, KQT-like } \\
\text { subfamily, member } 2\end{array}$ & $\begin{array}{l}\text { BFNS; Early infantile epi- } \\
\text { sodic encephalopathy }\end{array}$ & ENSRNOT00000016574 & -1.0 & $2.5 \mathrm{E}-03$ & $6.4 \mathrm{E}-02$ \\
\hline Atp2a2 & $\begin{array}{l}\text { ATPase, } \mathrm{Ca}++ \text { transport- } \\
\text { ing, cardiac muscle, slow } \\
\text { twitch } 2\end{array}$ & Darier-White disease & ENSRNOT00000067047 & -0.9 & $3.4 \mathrm{E}-03$ & $7.4 \mathrm{E}-02$ \\
\hline Kcna2 & $\begin{array}{l}\text { Potassium voltage-gated } \\
\text { channel, shaker-related } \\
\text { subfamily, member } 2\end{array}$ & $\begin{array}{l}\mathrm{Kcna} 2^{-/-} \text {with seizure } \\
\text { phenotype; Episodic } \\
\text { ataxia }\end{array}$ & ENSRNOT00000050149 & -0.9 & $3.9 \mathrm{E}-03$ & $7.9 \mathrm{E}-02$ \\
\hline
\end{tabular}

According to Gene Cards, JaxMice Database and Lemke et al. [40]

$\log F C \log 2$ fold change, leading sign indicates direction of change ( + , increase; - , decrease), $F D R$ false discovery rate, $B F N S$ benign familial neonatal seizures, $G E F S+$ generalized epilepsy with febrile seizures plus, $I G E$ idiopathic generalized epilepsy, $J M E$ juvenile myoclonic epilepsy

approaches, using independent assays such as bisulfite sequencing and qRT-PCR, respectively.

Ketogenic diet ameliorates seizure-induced DNA methylation in chronic rat epilepsy

Next we explored whether anti-epileptic treatment could change DNA methylation mediated gene expression in our experimental animal model, because medically refractory epilepsies frequently respond to strict dietary regimens. Indeed, the ketogenic diet (KD), a high-fat, moderate protein diet with low carbohydrate content has been implicated in regulating gene expression by modifying chromatin structure [68]. To test our hypothesis that a ketogenic diet could alter DNA methylation mediated gene expression we fed a subset of animals with a non-calorie restricted KD (PILO + KD) immediately following SE. KD treatment had no effect on SE as the initial precipitating injury. We tested ketosis as reliable parameter that the KD changed the animals' metabolism 2 weeks after initial treatment using standard reagent strips for urine analysis, i.e., "ketosticks" (Bayer, Leverkusen, Germany; Supplement Fig. 2). To assess any effect of dietary treatment on clinical phenotype, behavioral seizures were continuously monitored 
Table 4 Epigenetic signature in gene expression

\begin{tabular}{|c|c|c|c|c|c|c|}
\hline GeneID & Gene name & Function & Ensembl transcript ID & $\log \mathrm{FC}$ & $p$ value & FDR \\
\hline Gadd45a & $\begin{array}{l}\text { Growth arrest and DNA-dam- } \\
\text { age-inducible } 45 \text { alpha }\end{array}$ & $\begin{array}{l}\text { DNA demethylation, base exci- } \\
\text { sion repair }\end{array}$ & ENSRNOT00000007698 & 1.42 & $2.2 \mathrm{E}-06$ & $3.6 \mathrm{E}-04$ \\
\hline Apobec1 & $\begin{array}{l}\text { Apolipoprotein B mRNA } \\
\text { editing enzyme, catalytic } \\
\text { polypeptide } 1\end{array}$ & $\begin{array}{l}\text { DNA demethylation, cytidine } \\
\text { deaminase, base excision } \\
\text { repair }\end{array}$ & ENSRNOT00000020735 & 1.27 & $3.5 \mathrm{E}-04$ & $1.7 \mathrm{E}-02$ \\
\hline Eif2c1 & $\begin{array}{l}\text { Eukaryotic translation initia- } \\
\text { tion factor } 2 \mathrm{C}, 1 \text {; argonaute } \\
1\end{array}$ & $\begin{array}{l}\text { miR pathway, inhibition of } \\
\text { translation }\end{array}$ & ENSRNOT00000037728 & -0.94 & $8.6 \mathrm{E}-04$ & $3.4 \mathrm{E}-02$ \\
\hline Ncoa1 & Nuclear receptor coactivator 1 & $\begin{array}{l}\text { HAT activity towards } \mathrm{H} 3 \text { and } \\
\mathrm{H} 4 \text {, participates in chromatin } \\
\text { remodeling and recruitment } \\
\text { of general transcription factors }\end{array}$ & ENSRNOT00000005782 & -0.89 & $1.0 \mathrm{E}-03$ & $3.7 \mathrm{E}-02$ \\
\hline Ezh1 & Enhancer of zeste homolog 1 & HMT activity, H3K27 specific & ENSRNOT00000027640 & -0.87 & $1.1 \mathrm{E}-03$ & $3.8 \mathrm{E}-02$ \\
\hline Zmynd8 & $\begin{array}{l}\text { Zinc finger, MYND-type } \\
\text { containing } 8\end{array}$ & Chromatin remodeling factor & ENSRNOT00000025932 & -0.80 & $1.7 \mathrm{E}-03$ & $5.0 \mathrm{E}-02$ \\
\hline Mthfs & $\begin{array}{l}5,10 \text {-methenyltetrahydrofolate } \\
\text { synthetase }\end{array}$ & $\begin{array}{l}\text { Folate metabolism and trans- } \\
\text { methylation pathway }\end{array}$ & ENSRNOT00000039850 & 1.14 & $3.9 \mathrm{E}-03$ & $7.9 \mathrm{E}-02$ \\
\hline M111 & $\begin{array}{l}\text { Myeloid/lymphoid or mixed- } \\
\text { lineage leukemia } 1\end{array}$ & HMT activity, H3K4 specific & ENSRNOT00000020573 & -0.87 & $5.3 \mathrm{E}-03$ & $9.4 \mathrm{E}-02$ \\
\hline Nrip1 & $\begin{array}{l}\text { Nuclear receptor interacting } \\
\text { protein } 1\end{array}$ & $\begin{array}{l}\text { Serves as a scaffold for both } \\
\text { DNMT and HMT activities to } \\
\text { inhibit gene transcription }\end{array}$ & ENSRNOT00000002152 & -0.82 & $5.4 \mathrm{E}-03$ & $9.5 \mathrm{E}-02$ \\
\hline $\operatorname{Cbx} 5$ & Chromobox 5 & HP1 homolog, binding of $5 \mathrm{mC}$ & ENSRNOT00000055289 & 0.72 & $5.5 \mathrm{E}-03$ & $9.6 \mathrm{E}-02$ \\
\hline
\end{tabular}

According to GO terms and manual inspection

$\log F C \log 2$ fold change, leading sign indicates direction of change (+, increase; - , decrease), FDR false discovery rate, DNMT DNA methyltransferase, HAT Histone acetyltransferase, HMT Histone methyltransferase, $m i R$ microRNA, 5mC 5-methyl-cytosin
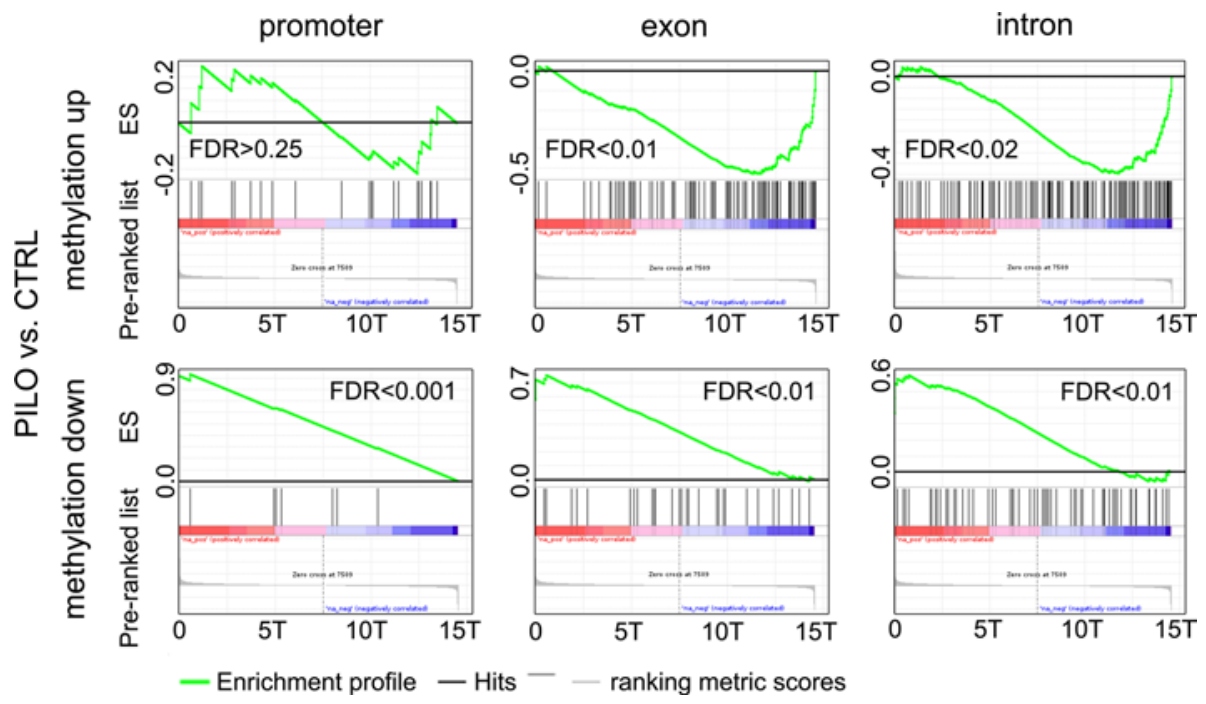

Fig. 4 Gene set enrichment analysis (GSEA) of methylated promoters, TSS and gene bodies were performed against the rank of our mRNA-Seq data from same samples. GSEA was separately performed for gene sets showing increased or decreased methylation in chronic rat epilepsy. A strong correlation (FDR $<0.25$ was considered significant) was observed between gene body methylation and

during the entire study period of 12 weeks after SE. Compared to SE-experienced animals fed a standard diet, KD administration did not result in differences regarding gene repression, and conversely, between loss of intragenic methylation and activated gene expression. Promoter hypermethylation was not associated with gene repression. $F D R$ false discovery rate, $T$ thousand, CTRL sham injected, healthy controls, PILO pilocarpine injected, chronic epileptic animals. Supplement Table 1 contains comprehensive GSEA statistics

latency period or mean severity and duration of clinical seizures. A significant difference, however, was detected according to seizure frequency per week (paired two-tailed 

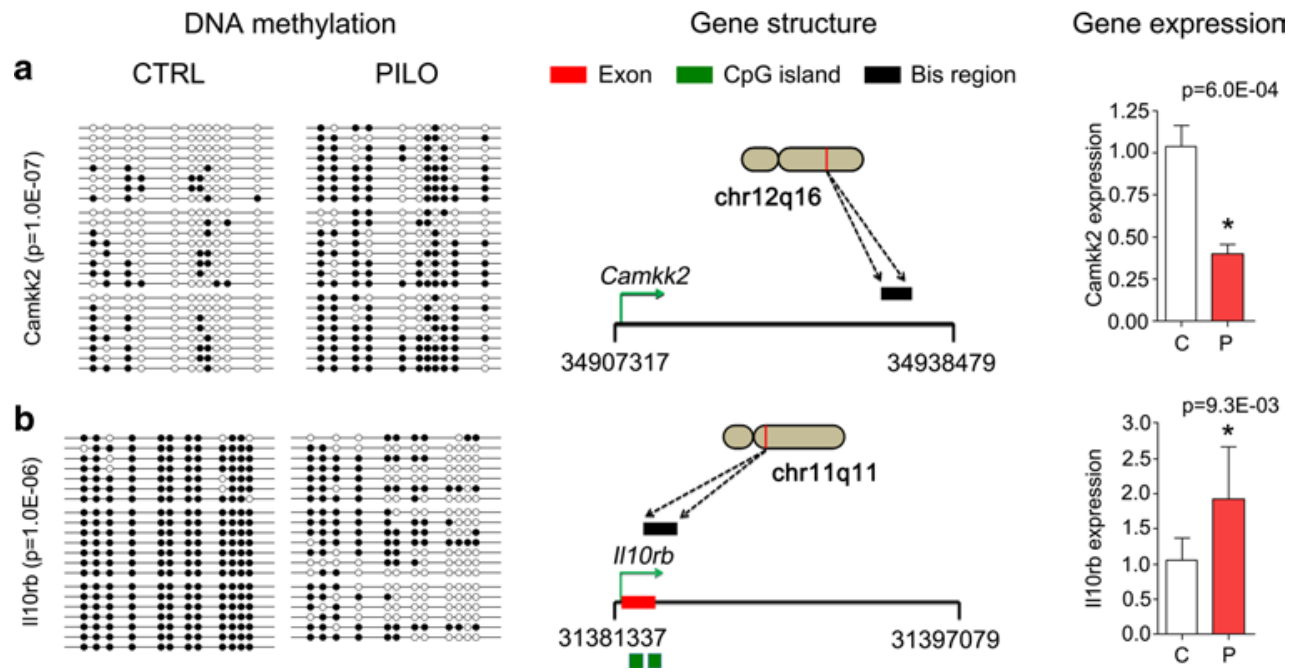

Fig. 5 Left panel showing bisulfite sequencing results (Bis-Seq, $n=3$ ). White dots represent unmethylated and black dots methylated CpGs. Middle panel summarizing schematic gene structure with TSS (green arrow), chromosomal region and region covered in Bis-Seq. Right panel presenting gene expression data from RT-PCR $(n=5)$. $C, C T R L$ control (white bar); P, PILO chronic epileptic animals

$t$ test, $p=4.0 \mathrm{E}-04$; mean \pm SEM: PILO $=24.5 \pm 4.7$, $\mathrm{PILO}+\mathrm{KD}=6.9 \pm 1.9$ ) with a reduction in seizure burden upon KD treatment and apparent delay in the chronification of the disease (Supplement Fig. 1b). Recordings from subdural electrodes and limited sample numbers with vEEG-monitoring did not allow meaningful quantification of KD effects on EEG data, but comparison of Racine stage 5 clinical seizures and baseline EEG provided no evidence for treatment specific differences between PILO and PILO + KD (Supplement Fig. 1c).

We analyzed differential methylation in epileptic animals assigned to anti-epileptic dietary treatment. Pairwise analysis of PILO + KD versus CTRL identified 1,785 loci that were differentially methylated. Thereof, 1,003 loci associated with hypermethylation and 782 regions with hypomethylation. Interestingly, the targeted genomic regions showed limited overlap with regions previously identified in our untreated epileptic PILO animals (Fig. 6a, blue). In KD-treated animals we observed strong reduction in DNA methylation at gene bodies as well as intronic and exonic regions. These results clearly show that genomic DNA methylation patterns of CTRL and PILO animals are distinguishable from the PILO $+\mathrm{KD}$ group. All animals from the PILO and PILO $+\mathrm{KD}$ group experienced convulsive seizures within $48 \mathrm{~h}$ preceding their termination (unpaired two-tailed $t$ test, $p>0.05$ ), suggesting that differences in methylation between groups were not dependent on the time point of their last seizure.

Gene expression profiling in KD-treated rats identified 400 differentially regulated genes compared to over 1,500 (red bar). Asterisks indicate significance (unpaired two-tailed $t$ test, $p<0.05$ ). a Camkk 2 showed hypermethylation and concomitant gene repression in PILO versus CTRL. b Hypomethylation of the Il10rb locus and increased gene expression could be confirmed in PILO versus CTRL

aberrantly expressed genes in PILO (cut-off $p<0.01$; Fig. 6b). Gene expression again was inversely correlated with genomic DNA methylation patterns (Supplement Table 1). To determine whether expression changes were associated with the anti-seizure phenotype and not induced by the diet, we compared our mRNA-Seq data with a recently described gene expression profile (GEO Data Set 954) derived from healthy, non-epileptic rats receiving a KD [10]. Consistent with our hypothesis that an anti-convulsive dietary treatment could alter DNA methylation mediated gene expression in rat epilepsy there was no correlation between the reference CTRL $+\mathrm{KD}$ and our PILO + KD (data not shown).

Validation experiments of our candidate genes, Camkk2 and Il10rb, provide additional evidence that the ketogenic diet may be useful to ameliorate aberrant seizure-associated DNA methylation (Mann-Whitney $U$ test, $p_{\text {Camkk } 2}=2.5 \mathrm{E}-$ 02 and $p_{\text {Il10rb }}=2.1 \mathrm{E}-02$; Fig. $6 \mathrm{c}$ ) and concomitant gene expression (one-way ANOVA with Bonferroni post hoc test, $p_{\text {Camkk } 2}=3.4 \mathrm{E}-03$ and $p_{\text {II10rb }}=2.0 \mathrm{E}-02$; Fig. $6 \mathrm{~d}$ ).

Gene expression profiles reveal further regulatory pathways implicated in chronic epilepsy

Gene expression is coordinated by complex regulatory mechanisms that involve transcription factor binding and chromatin modification including DNA methylation. To explore mechanisms that serve to regulate coordinated gene expression changes in chronic rat epilepsy we examined our mRNA-Seq data for changes consistent with 


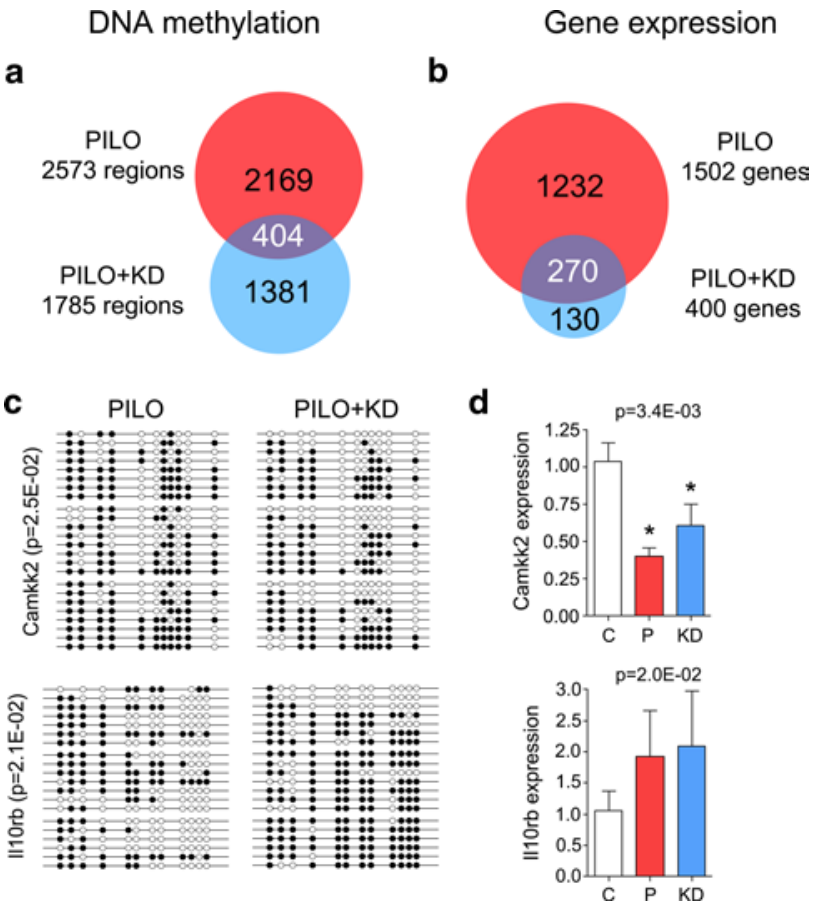

Fig. 6 Comparison of differential DNA methylation and gene expression patterns in pilocarpine injected, epileptic animals receiving anti-convulsive ketogenic diet (PILO $+\mathrm{KD}$, blue) or no treatment (PILO, red). The KD treatment partially ameliorated molecular changes associated with chronic rat epilepsy. Effects were more pronounced on a genomic scale than at certain loci of selected candidate genes. a Venn diagram displaying overlap in differential DNA methylation between PILO and PILO + KD compared to CTRL. KD-treated animals showed a distinct genomic methylation profile compared to untreated chronic rat epilepsy. Administration of the KD seemed to have rescued a majority of affected loci. b Venn diagram displaying overlap in differential gene expression between PILO and PILO + KD compared to CTRL. KD-treated animals showed a distinct gene expression pattern compared to untreated chronic rat epilepsy. A majority of differentially expressed genes in PILO were rescued upon KD treatment. Genes exclusively expressed in PILO + KD may have contributed to adverse side effects. c Bisulfite sequencing results. Camkk2 hypermethylation in PILO animals was significantly reduced by $\mathrm{KD}$ treatment (Mann-Whitney $U$ test, $p<0.05$ ). Further, hypomethylation of the Il10rb locus in PILO was reversed in $\mathrm{KD}+$ PILO. White dots represent unmethylated and black dots methylated CpGs. d Gene expression of Camkk2 and I110rb in PILO and PILO + KD. KD treatment partially rescued Camkk2 gene expression, but had no significant effect on Il10rb. $C, C T R L$ control (white bar); $P, P I L O$ chronic epileptic animals (red bar); KD, PILO $+K D$ pilocarpine injected animals receiving anti-convulsive ketogenic dietary treatment (blue bar). Asterisks indicate significance (univariate one-way ANOVA followed by Bonferroni post hoc test, $p<0.05$ )

transcription factor signaling using GSEA. We found that genes downregulated in our epilepsy model (PILO and PILO + KD) shared binding motifs for neuron restrictive silencing factor (Nrsf) and suppressor of zeste 12 (Suz12). The former is a major transcriptional regulator of neuronal gene expression that recruits Dnmts and Hdacs, and the latter is a central component of the Polycomb repressor complex 2 (Prc2). Downregulated genes from PILO and PILO + KD animals with Suz12/Prc2 binding capacity were generally hypomethylated, consistent with a recent study [24]. Examination of upregulated genes in PILO and PILO + KD animals identified that nuclear factor kappa B (Nfkb), K(lysine) acetyltransferase 2 (Kat2a), zinc finger ZZ domain containing 3 (Zzz3), general transcription factor IIB (Gtf2b) and p300 binding motifs were commonly shared. Nfkb is a rapidly acting primary transcription factor that plays a key role in regulating inflammation and immune response also in epilepsy [74]. Kat2a, Zzz3 and p300 are distinguished transcriptional activators, which share histone acetyltransferase activity [70]. Taken together, our results indicate that important transcription factors, which serve to function in chromatin modification, together with DNA methylation may participate in regulating common patterns of gene expression in chronic epilepsy.

\section{Discussion}

This is the first report describing genome-wide changes in DNA methylation in the chronic stage of rat TLE. Dissecting rat hippocampal tissue, mRNA sequencing identified deregulation of seizure- and epilepsy-related genes, metabolic and key epigenetic enzymes or regulators. DNA methylation was found to be inversely correlated with gene expression, and candidate genes were validated using bisulfite sequencing and real-time PCR. Ketogenic diet, a well recognized anti-epileptic treatment in children with severe, chronic epilepsy [13, 54], attenuated seizure burden, delayed chronification of the disease and partially rescued the DNA methylation and corresponding gene expression phenotype.

DNA methylation not only regulates cell fate determination and maturation in the brain but also plays a role for the induction of activity-dependent synaptic plasticity, memory and cognition [20,41, 42, 60]. The importance of epigenetic tuning of higher order brain function is emphasized by a growing number of neurological diseases that associate with alterations in DNA methylation, including autism spectrum disorders, schizophrenia, Alzheimer's disease, brain tumors, spinal muscular atrophy and, more recently, epilepsy [35]. So far, epigenetic gene regulation in epileptogenesis had only been investigated for individual candidate genes (e.g., Reelin, BDNF, GluR2) and/or focused on the very early stage of the disease, during or immediately following SE [36, 47, 53, 73]. Our present study is unique for its simultaneous DNA methylation and gene expression profiling, suggesting DNA methylation as potential molecular pathomechanism in chronic epilepsy contributing to the deregulation of multiple genes. 
We observed specific DNA methylation signatures, which readily discriminate chronic epileptic PILO from reference CTRL and PILO + KD animals using hierarchical cluster analysis. Genome-wide unsupervised clustering of an epigenetic mark could distinguish epileptic from non-epileptic animals. We observed more frequent hypermethylation of genes in rats with chronic epilepsy. Indeed, changes in DNA methylation were predominantly located at CGIs within gene bodies, and generally did not target gene promoters. A similar pattern of gene body methylation was recently described in the healthy rat and human methylome [15, 67]. In this study, DNA methylation was inversely correlated with gene expression. Targeted validation experiments supported this finding, providing some evidence for the biological significance of seizure-associated DNA methylation changes. Both hyper- and hypomethylation events were detected with subsequent gene repression or activation. The calcium/calmodulin-dependent protein kinase kinase 2, beta (Camkk2) was down-regulated in our chronic epileptic animals when compared to controls and showed intragenic hypermethylation. Camkk2 is a key enzyme in calcium signaling, which mainly phosphorylates Camk1 and Camk4 as well as AMP-activated protein kinase (Ampk). It further seems to be involved in hippocampal activation of the transcription factor cAMP response element binding protein (Creb1) and downstream immediate early genes [62]. Camkk2 is highly expressed in the brain, and involved in long-term potentiation and hippocampus-dependent memory formation [56], granule cell development [37] and cortical axon elongation [2]. Thus, altered expression of Camkk2 may contribute to seizureassociated memory impairment. In contrast, the Il10rb was hypomethylation in the chronic epileptic PILO cohort and this was consistent with increased gene expression. Il10rb belongs to the cytokine receptor family and is an essential accessory chain for the active IL-10 receptor complex. The localization of the $\mathrm{IL}-10$ receptor in five major regions of the rat brain including hippocampus supports a central role in inflammation signaling [76]. Interestingly, the expression of IL-10 is elevated during the course of most major diseases in the CNS including TLE and promotes survival of neurons and all glial cells in the brain by blocking the effects of proapoptotic cytokines and promoting expression of cell survival signals [32, 71]. Therefore, overexpression of IL10rb in rat epilepsy could be a compensatory mechanism to limit brain damage following seizures.

Genome-wide profiling also clearly identified methylation changes that did not correspond with gene expression changes. Transcriptional regulation is dependent on several mechanisms that include chromatin remodeling, microRNAs, histone modifications as well as transcription factor binding together with DNA methylation. Consistent with this, we identified differential gene expression for a number of epigenetic enzymes (Table 4) as well as binding motifs for key transcriptional activators (Nfkb, Kat2a, Zzz3, Gtf2b, p300) and repressors (Nrsf, Suz12) overrepresented in our gene sets. Interestingly, some transcription factors also function to regulate chromatin structure [3, 29, 46, 70]. Our analysis highlighted Prc2 interaction conferred by Suz12. Previous studies suggest that the Prc2 complex may serve as a recruiting platform also for Dnmts, thereby linking two epigenetic repression systems [66, 75]. Our data do not support this interplay as downregulated genes with Suz12 response element did not show increased DNA methylation. This finding is in line with recent studies, where authors showed that trimethylation of histone 3 lysine 27 (H3K27) and DNA methylation are mutually exclusive particularly at CGIs [11, 24]. Taken together, our in silico analysis of common transcription factor binding motifs supports a model of transcriptional regulation in chronic rat epilepsy, where gene activation is conferred by histone acetylation and gene suppression mediated by antagonistic effects of DNA and histone methylation.

In this study, DNA methylation provided a strong signal to separate chronic epileptic rats from healthy controls, but it remained unsolved, whether the presence of spontaneous seizures (epilepsy) led to altered methylation, or if altered methylation influenced seizures. To test the first hypothesis, we analyzed whether early administration of a high-fat, high-protein, low-carbohydrate ketogenic diet (KD) would partially rescue the seizure-associated and gene regulating DNA methylation changes in our rat TLE model. The KD is a clinically effective treatment in children with epilepsy and severe cognitive impairment, pharmacoresistant to conventional and even newer anti-convulsant medications [54]. We show that KD administration in our epilepsy model partially attenuated seizure burden, delayed disease progression and interfered with aberrant seizure-related genomic and locus specific alterations in DNA methylation and gene expression. How the ketogenic diet works to control or attenuate seizures remains poorly understood [13, 48]. The mechanisms proposed include metabolic changes (restricting glycolysis, increasing fatty acid oxidation, mitochondrial respiration and ATP synthesis), increased GABAergic inhibition, modulation of oxidative stress and neuroprotection [63]. It is most likely that described mechanisms work complementary, and we suggest that direct or indirect induction of epigenetic changes may add to this complexity [23, 49, 68].

Consistent with our hypothesis that gene expression changes associated with the anti-seizure phenotype, we compared a differential gene list derived from a recent study involving also non-epileptic KD-treated control animals [10] with the rank of our PILO + KD cohort. Comparison of data sets showed no correlation of gene expression patterns with diet, supporting the idea that 
the anti-convulsive properties of the $\mathrm{KD}$ contribute to DNA methylation mediated gene expression changes in PILO + KD. Future studies could determine whether DNA methylation affects seizures using known DNMT inhibitors. Since they have not been tested thoroughly this remains speculative. The proposed relationship between neuronal hypersynchronous activity and gene regulation mediated by epigenetic changes could also be explored beyond the present study design to address timing and signal transition from the acute to the chronic disease phase as well as cell-specificity of epigenetic events. We cannot exclude that regional differences in DNA methylation and gene expression in our study may have been masked in part using whole hippocampus. Prospective utilization of microdissected homogenous cell populations from specific hippocampal subfields will help to decipher where exactly seizure-related DNA methylation changes occur (e.g., glia or the neuronal subpopulations of pyramidal and granular cells), and which of the detected signals in the present study were only related to cell composition effects in the different samples.

In conclusion, the characterization of mechanisms underlying epigenetic changes in the chronic epileptic brain should lead to a better understanding of disease. We consider that our genome-wide analyses provide a comprehensive profile of DNA methylation mediated gene expression changes, and may help to identify new regulatory targets in epilepsy, which again could be addressed by novel treatment strategies. By defining the principal events mediating epigenomic changes it is anticipated that novel approaches will be developed to inhibit, attenuate or reverse the persistent deleterious consequences of seizures in the epileptic brain.

Acknowledgments We kindly thank T. Jungbauer and B. Rings for their expert technical assistance. This work was supported by EpiGENet (DFG Bl 421/3-1). Assam El-Osta is an NHMRC Senior Research Fellow.

Conflict of interest All authors confirm that there is no conflict of interest in relation to this article.

Open Access This article is distributed under the terms of the Creative Commons Attribution License which permits any use, distribution, and reproduction in any medium, provided the original author(s) and the source are credited.

\section{References}

1. NCBI Resource Coordinators (2013) Database resources of the National Center for Biotechnology Information. Nucleic Acids Res 41:D8-D20

2. Ageta-Ishihara N, Takemoto-Kimura S, Nonaka M, AdachiMorishima A, Suzuki K, Kamijo S, Fujii H, Mano T, Blaeser F, Chatila TA, Mizuno H, Hirano T, Tagawa Y, Okuno H, Bito
$\mathrm{H}$ et al (2009) Control of cortical axon elongation by a GABAdriven $\mathrm{Ca} 2+/$ calmodulin-dependent protein kinase cascade. $\mathrm{J}$ Neurosci 29:13720-13729

3. Allis CD, Jenuwein T, Reinberg D, Caparros M-L (eds) (2007) Epigenetics. Cold Spring Harbor Laboratory Press Cold Spring Harbor, New York

4. Becker AJ, Chen J, Zien A, Sochivko D, Normann S, Schramm J, Elger CE, Wiestler OD, Blumcke I et al (2003) Correlated stageand subfield-associated hippocampal gene expression patterns in experimental and human temporal lobe epilepsy. Eur J Neurosci 18:2792-2802

5. Becker AJ, Pitsch J, Sochivko D, Opitz T, Staniek M, Chen CC, Campbell KP, Schoch S, Yaari Y, Beck H et al (2008) Transcriptional upregulation of Cav3.2 mediates epileptogenesis in the pilocarpine model of epilepsy. J Neurosci 28:13341-13353

6. Benjamini Y, Hochberg Y (1995) Controlling the false discovery rate: a practical and powerful approach to multiple testing. $\mathrm{J}$ Royal Stat Soc Ser B (Methodol) 57:289-300

7. Blumcke I, Coras R, Miyata H, Ozkara C et al (2012) Defining clinico-neuropathological subtypes of mesial temporal lobe epilepsy with hippocampal sclerosis. Brain Pathol 22:402-411

8. Blumcke I, Pauli E, Clusmann H, Schramm J, Becker A, Elger C, Merschhemke M, Meencke HJ, Lehmann T, von Deimling A, Scheiwe C, Zentner J, Volk B, Romstock J, Stefan H, Hildebrandt $M$ et al (2007) A new clinico-pathological classification system for mesial temporal sclerosis. Acta Neuropathol 113:235-244

9. Blumcke I, Thom M, Aronica E, Armstrong DD, Bartolomei F, Bernasconi A, Bernasconi N, Bien CG, Cendes F, Coras R, Cross JH, Jacques TS, Kahane P, Mathern GW, Miyata H, Moshe SL, Oz B, Ozkara C, Perucca E, Sisodiya S, Wiebe S, Spreafico R et al (2013) International consensus classification of hippocampal sclerosis in temporal lobe epilepsy: a task force report from the ILAE Commission on diagnostic methods. Epilepsia 54(7):1315-1329

10. Bough KJ, Wetherington J, Hassel B, Pare JF, Gawryluk JW, Greene JG, Shaw R, Smith Y, Geiger JD, Dingledine RJ et al (2006) Mitochondrial biogenesis in the anticonvulsant mechanism of the ketogenic diet. Ann Neurol 60:223-235

11. Brinkman AB, Gu H, Bartels SJ, Zhang Y, Matarese F, Simmer F, Marks H, Bock C, Gnirke A, Meissner A, Stunnenberg HG et al (2012) Sequential ChIP-bisulfite sequencing enables direct genome-scale investigation of chromatin and DNA methylation cross-talk. Genome Res 22:1128-1138

12. Brinkman AB, Simmer F, Ma K, Kaan A, Zhu J, Stunnenberg HG et al (2010) Whole-genome DNA methylation profiling using MethylCap-seq. Methods 52:232-236

13. Cross JH (2013) New research with diets and epilepsy. J Child Neurol 28:970-974

14. Crowe SL, Tsukerman S, Gale K, Jorgensen TJ, Kondratyev AD et al (2011) Phosphorylation of histone H2A.X as an early marker of neuronal endangerment following seizures in the adult rat brain. J Neurosci 31:7648-7656

15. Deaton AM, Webb S, Kerr AR, Illingworth RS, Guy J, Andrews R, Bird A et al (2011) Cell type-specific DNA methylation at intragenic $\mathrm{CpG}$ islands in the immune system. Genome Res 21:1074-1086

16. Elliott RC, Miles MF, Lowenstein DH (2003) Overlapping microarray profiles of dentate gyrus gene expression during development- and epilepsy-associated neurogenesis and axon outgrowth. J Neurosci 23:2218-2227

17. ENCODE Project Consortium, Bernstein BE, Birney E, Dunham I, Green ED, Gunter C, Snyder M et al (2012) An integrated encyclopedia of DNA elements in the human genome. Nature 489:57-74

18. Feil R, Fraga MF (2012) Epigenetics and the environment: emerging patterns and implications. Nat Rev Genet 13:97-109 
19. Feng J, Zhou Y, Campbell SL, Le T, Li E, Sweatt JD, Silva AJ, Fan G et al (2010) Dnmt1 and Dnmt3a maintain DNA methylation and regulate synaptic function in adult forebrain neurons. Nat Neurosci 13:423-430

20. Fischer A, Sananbenesi F, Wang X, Dobbin M, Tsai LH et al (2007) Recovery of learning and memory is associated with chromatin remodelling. Nature 447:178-182

21. Garriga-Canut M, Schoenike B, Qazi R, Bergendahl K, Daley TJ, Pfender RM, Morrison JF, Ockuly J, Stafstrom C, Sutula T, Roopra A et al (2006) 2-Deoxy-D-glucose reduces epilepsy progression by NRSF-CtBP-dependent metabolic regulation of chromatin structure. Nat Neurosci 9:1382-1387

22. Gorter JA, van Vliet EA, Aronica E, Breit T, Rauwerda H, Lopes da Silva FH, Wadman WJ et al (2006) Potential new antiepileptogenic targets indicated by microarray analysis in a rat model for temporal lobe epilepsy. J Neurosci 26:11083-11110

23. Greene RW (2011) Adenosine: front and center in linking nutrition and metabolism to neuronal activity. $\mathrm{J}$ Clin Invest 121:2548-2550

24. Hagarman JA, Motley MP, Kristjansdottir K, Soloway PD (2013) Coordinate regulation of DNA methylation and $\mathrm{H} 3 \mathrm{~K} 27 \mathrm{me} 3$ in mouse embryonic stem cells. PLoS One 8:e53880

25. Harikrishnan KN, Bayles R, Ciccotosto GD, Maxwell S, Cappai R, Pelka GJ, Tam PP, Christodoulou J, El-Osta A et al (2010) Alleviating transcriptional inhibition of the norepinephrine slc6a2 transporter gene in depolarized neurons. J Neurosci 30:1494-1501

26. Hendriksen H, Datson NA, Ghijsen WE, van Vliet EA, da Silva FH, Gorter JA, Vreugdenhil E et al (2001) Altered hippocampal gene expression prior to the onset of spontaneous seizures in the rat post-status epilepticus model. Eur J Neurosci 14:1475-1484

27. da Huang W, Sherman BT, Lempicki RA (2009) Systematic and integrative analysis of large gene lists using DAVID bioinformatics resources. Nat Protoc 4:44-57

28. Huang Y, Doherty JJ, Dingledine R (2002) Altered histone acetylation at glutamate receptor 2 and brain-derived neurotrophic factor genes is an early event triggered by status epilepticus. J Neurosci 22:8422-8428

29. Huang Y, Myers SJ, Dingledine R (1999) Transcriptional repression by REST: recruitment of Sin3A and histone deacetylase to neuronal genes. Nat Neurosci 2:867-872

30. Jia YH, Zhu X, Li SY, Ni JH, Jia HT et al (2006) Kainate exposure suppresses activation of GluR2 subunit promoter in primary cultured cerebral cortical neurons through induction of RE1silencing transcription factor. Neurosci Lett 403:103-108

31. Jimenez-Mateos EM, Engel T, Merino-Serrais P, McKiernan RC, Tanaka K, Mouri G, Sano T, O'Tuathaigh C, Waddington JL, Prenter S, Delanty N, Farrell MA, O'Brien DF, Conroy RM, Stallings RL, Defelipe J, Henshall DC et al (2012) Silencing microRNA-134 produces neuroprotective and prolonged seizuresuppressive effects. Nat Med 18:1087-1094

32. Kan AA, de Jager W, de Wit M, Heijnen C, van Zuiden M, Ferrier $\mathrm{C}$, van Rijen $\mathrm{P}$, Gosselaar $\mathrm{P}$, Hessel E, van Nieuwenhuizen $\mathrm{O}$, de Graan PN et al (2012) Protein expression profiling of inflammatory mediators in human temporal lobe epilepsy reveals coactivation of multiple chemokines and cytokines. J Neuroinflamm 9:207

33. Kobow K, Auvin S, Jensen F, Loscher W, Mody I, Potschka H, Prince D, Sierra A, Simonato M, Pitkanen A, Nehlig A, Rho JM et al (2012) Finding a better drug for epilepsy: antiepileptogenesis targets. Epilepsia 53:1868-1876

34. Kobow K, Blumcke I (2011) The methylation hypothesis: do epigenetic chromatin modifications play a role in epileptogenesis? Epilepsia 52(Suppl 4):15-19

35. Kobow K, Blumcke I (2012) The emerging role of DNA methylation in epileptogenesis. Epilepsia 53(Suppl 9):11-20
36. Kobow K, Jeske I, Hildebrandt M, Hauke J, Hahnen E, Buslei R, Buchfelder M, Weigel D, Stefan H, Kasper B, Pauli E, Blumcke I et al (2009) Increased reelin promoter methylation is associated with granule cell dispersion in human temporal lobe epilepsy. J Neuropathol Exp Neurol 68:356-364

37. Kokubo M, Nishio M, Ribar TJ, Anderson KA, West AE, Means AR et al (2009) BDNF-mediated cerebellar granule cell development is impaired in mice null for CaMKK2 or CaMKIV. J Neurosci 29:8901-8913

38. Kossoff EH, Hartman AL (2012) Ketogenic diets: new advances for metabolism-based therapies. Curr Opin Neurol 25:173-178

39. Krzywinski M, Schein J, Birol I, Connors J, Gascoyne R, Horsman D, Jones SJ, Marra MA et al (2009) Circos: an information aesthetic for comparative genomics. Genome Res 19:1639-1645

40. Lemke JR, Riesch E, Scheurenbrand T, Schubach M, Wilhelm C, Steiner I, Hansen J, Courage C, Gallati S, Burki S, Strozzi S, Simonetti BG, Grunt S, Steinlin M, Alber M, Wolff M, Klopstock T, Prott EC, Lorenz R, Spaich C, Rona S, Lakshminarasimhan M, Kroll J, Dorn T, Kramer G, Synofzik M, Becker F, Weber YG, Lerche H, Bohm D, Biskup S et al (2012) Targeted next generation sequencing as a diagnostic tool in epileptic disorders. Epilepsia 53:1387-1398

41. Levenson JM, Roth TL, Lubin FD, Miller CA, Huang IC, Desai P, Malone LM, Sweatt JD et al (2006) Evidence that DNA (cytosine-5) methyltransferase regulates synaptic plasticity in the hippocampus. J Biol Chem 281:15763-15773

42. Levenson JM, Sweatt JD (2005) Epigenetic mechanisms in memory formation. Nat Rev Neurosci 6:108-118

43. Li H, Durbin R (2009) Fast and accurate short read alignment with Burrows-Wheeler transform. Bioinformatics 25:1754-1760

44. Liu M, Sheng Z, Cai L, Zhao K, Tian Y, Fei J et al (2012) Neuronal conditional knockout of NRSF decreases vulnerability to seizures induced by pentylenetetrazol in mice. Acta Biochim Biophys $\operatorname{Sin} 44: 476-482$

45. Lukasiuk K, Dabrowski M, Adach A, Pitkanen A et al (2006) Epileptogenesis-related genes revisited. Prog Brain Res 158: 223-241

46. Margueron R, Reinberg D (2011) The Polycomb complex PRC2 and its mark in life. Nature 469:343-349

47. Martinowich K, Hattori D, Wu H, Fouse S, He F, Hu Y, Fan G, Sun YE et al (2003) DNA methylation-related chromatin remodeling in activity-dependent BDNF gene regulation. Science 302:890-893

48. Masino SA, Kawamura M Jr, Ruskin DN, Geiger JD, Boison D et al (2012) Purines and neuronal excitability: links to the ketogenic diet. Epilepsy Res 100:229-238

49. Masino SA, Li T, Theofilas P, Sandau US, Ruskin DN, Fredholm BB, Geiger JD, Aronica E, Boison D et al (2011) A ketogenic diet suppresses seizures in mice through adenosine A receptors. $\mathrm{J}$ Clin Invest 121:2679-2683

50. Masino SA, Rho JM (2012) Mechanisms of ketogenic diet action. In: Noebels JL, Avoli M, Rogawski MA, Olsen RW, DelgadoEscueta AV (eds) Jasper's basic mechanisms of the epilepsies (contemporary neurology series). Oxford University Press, Oxford, pp 1003-1024

51. McClelland S, Flynn C, Dubé C, Richichi C, Zha Q, Ghestem A, Esclapez M, Bernard C, Baram TZ et al (2011) Neuron-restrictive silencer factor-mediated hyperpolarization-activated cyclic nucleotide gated channelopathy in experimental temporal lobe epilepsy. Ann Neurol 70:454-464

52. Mikkelsen TS, Ku M, Jaffe DB, Issac B, Lieberman E, Giannoukos G, Alvarez P, Brockman W, Kim TK, Koche RP, Lee W, Mendenhall E, O'Donovan A, Presser A, Russ C, Xie X, Meissner A, Wernig M, Jaenisch R, Nusbaum C, Lander ES, Bernstein $\mathrm{BE}$ et al (2007) Genome-wide maps of chromatin state in pluripotent and lineage-committed cells. Nature 448:553-560 
53. Miller-Delaney SF, Das S, Sano T, Jimenez-Mateos EM, Bryan K, Buckley PG, Stallings RL, Henshall DC et al (2012) Differential DNA methylation patterns define status epilepticus and epileptic tolerance. J Neurosci 32:1577-1588

54. Neal EG, Chaffe H, Schwartz RH, Lawson MS, Edwards N, Fitzsimmons G, Whitney A, Cross JH et al (2008) The ketogenic diet for the treatment of childhood epilepsy: a randomised controlled trial. Lancet Neurol 7:500-506

55. Okano M, Bell DW, Haber DA, Li E et al (1999) DNA methyltransferases Dnmt3a and Dnmt3b are essential for de novo methylation and mammalian development. Cell 99:247-257

56. Peters M, Mizuno K, Ris L, Angelo M, Godaux E, Giese KP et al (2003) Loss of Ca2+/calmodulin kinase kinase beta affects the formation of some, but not all, types of hippocampus-dependent long-term memory. J Neurosci 23:9752-9760

57. Pirola L, Balcerczyk A, Tothill RW, Haviv I, Kaspi A, Lunke S, Ziemann M, Karagiannis T, Tonna S, Kowalczyk A, BeresfordSmith B, Macintyre G, Kelong M, Hongyu Z, Zhu J, El-Osta A et al (2011) Genome-wide analysis distinguishes hyperglycemia regulated epigenetic signatures of primary vascular cells. Genome Res 21:1601-1615

58. Pitkanen A, Lukasiuk K (2011) Mechanisms of epileptogenesis and potential treatment targets. Lancet Neurol 10:173-186

59. Quinlan AR, Hall IM (2010) BEDTools: a flexible suite of utilities for comparing genomic features. Bioinformatics 26:841-842

60. Qureshi IA, Mehler MF (2010) Epigenetic mechanisms underlying human epileptic disorders and the process of epileptogenesis. Neurobiol Dis 39:53-60

61. Racine RJ (1972) Modification of seizure activity by electrical stimulation. II. Motor seizure. Electroencephalogr Clin Neurophysiol 32:281-294

62. Racioppi L, Means AR (2012) Calcium/calmodulin-dependent protein kinase kinase 2: roles in signaling and pathophysiology. $\mathrm{J}$ Biol Chem 287:31658-31665

63. Rho JM, Sankar R (2008) The ketogenic diet in a pill: is this possible? Epilepsia 49(Suppl 8):127-133

64. Robinson MD, McCarthy DJ, Smyth GK (2010) edgeR: a bioconductor package for differential expression analysis of digital gene expression data. Bioinformatics 26:139-140

65. Robinson MD, Oshlack A (2010) A scaling normalization method for differential expression analysis of RNA-seq data. Genome Biol 11:R25

66. Rush M, Appanah R, Lee S, Lam LL, Goyal P, Lorincz MC et al (2009) Targeting of EZH2 to a defined genomic site is sufficient for recruitment of Dnmt3a but not de novo DNA methylation. Epigenetics 4:404-414

67. Sati S, Tanwar VS, Kumar KA, Patowary A, Jain V, Ghosh S, Ahmad S, Singh M, Reddy SU, Chandak GR, Raghunath M,
Sivasubbu S, Chakraborty K, Scaria V, Sengupta S et al (2012) High resolution methylome map of rat indicates role of intragenic DNA methylation in identification of coding region. PLoS One 7:e31621

68. Shimazu T, Hirschey MD, Newman J, He W, Shirakawa K, Le Moan N, Grueter CA, Lim H, Saunders LR, Stevens RD, Newgard CB, Farese RV Jr, de Cabo R, Ulrich S, Akassoglou K, Verdin E et al (2013) Suppression of oxidative stress by betahydroxybutyrate, an endogenous histone deacetylase inhibitor. Science 339:211-214

69. Sng JC, Taniura H, Yoneda Y (2006) Histone modifications in kainate-induced status epilepticus. Eur J Neurosci 23:1269-1282

70. Sterner DE, Berger SL (2000) Acetylation of histones and transcription-related factors. Microbiol Mol Biol Rev 64:435-459

71. Strle K, Zhou JH, Shen WH, Broussard SR, Johnson RW, Freund GG, Dantzer R, Kelley KW et al (2001) Interleukin-10 in the brain. Crit Rev Immunol 21:427-449

72. Subramanian A, Tamayo P, Mootha VK, Mukherjee S, Ebert BL, Gillette MA, Paulovich A, Pomeroy SL, Golub TR, Lander ES, Mesirov JP et al (2005) Gene set enrichment analysis: a knowledge-based approach for interpreting genome-wide expression profiles. Proc Natl Acad Sci USA 102:15545-15550

73. Tsankova NM, Kumar A, Nestler EJ (2004) Histone modifications at gene promoter regions in rat hippocampus after acute and chronic electroconvulsive seizures. J Neurosci 24:5603-5610

74. Vezzani A, French J, Bartfai T, Baram TZ et al (2011) The role of inflammation in epilepsy. Nat Rev Neurol 7:31-40

75. Vire E, Brenner C, Deplus R, Blanchon L, Fraga M, Didelot C, Morey L, Van Eynde A, Bernard D, Vanderwinden J-M, Bollen M, Esteller M, Di Croce L, de Launoit Y, Fuks F et al (2006) The Polycomb group protein EZH2 directly controls DNA methylation. Nature 439:871-874

76. Ward H, Vigues S, Poole S, Bristow AF et al (2001) The rat interleukin 10 receptor: cloning and sequencing of cDNA coding for the alpha-chain protein sequence, and demonstration by western blotting of expression in the rat brain. Cytokine 15:237-240

77. Weber M, Hellmann I, Stadler MB, Ramos L, Paabo S, Rebhan M, Schubeler D et al (2007) Distribution, silencing potential and evolutionary impact of promoter DNA methylation in the human genome. Nat Genet 39:457-466

78. Zhang Y, Liu T, Meyer CA, Eeckhoute J, Johnson DS, Bernstein BE, Nusbaum C, Myers RM, Brown M, Li W, Liu XS et al (2008) Model-based analysis of ChIP-Seq (MACS). Genome Biol 9:R137

79. Zhu Q, Wang L, Zhang Y, Zhao FH, Luo J, Xiao Z, Chen GJ, Wang XF et al (2011) Increased expression of DNA methyltransferase 1 and $3 \mathrm{a}$ in human temporal lobe epilepsy. J Mol Neurosci 46:420-426 